\title{
Analysis of Sulfated Glycosaminoglycans in ECM Scaffolds for Tissue Engineering Applications: Modified Alcian Blue Method Development and Validation
}

\author{
Tuyajargal Iimaa ${ }^{1,2}$, Yasuhiro Ikegami ${ }^{1}$, Ronald Bual ${ }^{1,3} \oplus$, Nana Shirakigawa ${ }^{1} \oplus$ and \\ Hiroyuki Ijima ${ }^{1, *}$ \\ 1 Department of Chemical Engineering, Graduate School of Engineering, Kyushu University, 744 Motooka, \\ Nishi-Ku, Fukuoka 819-0395, Japan; tuyaiimaa@gmail.com (T.I.); y-ikegami@kyudai.jp (Y.I.); \\ ronald.bual@g.msuiit.edu.ph (R.B.); shirakigawa@chem-eng.kyushu-u.ac.jp (N.S.) \\ 2 Department of Biochemistry and Laboratory Medicine, School of Biomedicine, \\ Mongolian National University of Medical Sciences, Ulaanbaatar 14210, Mongolia \\ 3 Department of Chemical Engineering \& Technology, College of Engineering, \\ Mindanao State University-Iligan Insititute of Technology, Iligan 9200, Philippines \\ * Correspondence: ijima@chem-eng.kyushu-u.ac.jp; Tel./Fax: +81-92-802-2748
}

Received: 31 March 2019; Accepted: 29 April 2019; Published: 30 April 2019

\begin{abstract}
Accurate determination of the amount of glycosaminoglycans (GAGs) in a complex mixture of extracellular matrix (ECM) is important for tissue morphogenesis and homeostasis. The aim of the present study was to investigate an accurate, simple and sensitive alcian blue (AB) method for quantifying heparin in biological samples. A method for analyzing heparin was developed and parameters such as volume, precipitation time, solvent component, and solubility time were evaluated. The $\mathrm{AB}$ dye and heparin samples were allowed to react at $4{ }^{\circ} \mathrm{C}$ for $24 \mathrm{~h}$. The heparin- $\mathrm{AB}$ complex was dissolved in $25 \mathrm{~N} \mathrm{NaOH}$ and 2-Aminoethanol (1:24 v/v). The optical density of the solution was analyzed by UV-Vis spectrometry at $620 \mathrm{~nm}$. The modified AB method was validated in accordance with U.S. Food and Drug Administration guidelines. The limit of detection was found to be $2.95 \mu \mathrm{g} / \mathrm{mL}$. Intraday and interday precision ranged between $2.14-4.83 \%$ and $3.16-7.02 \%(\mathrm{n}=9)$, respectively. Overall recovery for three concentration levels varied between $97 \pm 3.5 \%$, confirming good accuracy. In addition, this study has discovered the interdisciplinary nature of protein detection using the $A B$ method. The basis for this investigation was that the fibrous protein inhibits heparin- $A B$ complex whereas globular protein does not. Further, we measured the content of sulfated GAGs (sGAGs; expressed as heparin equivalent) in the ECM of decellularized porcine liver. In conclusion, the $\mathrm{AB}$ method may be used for the quantitative analysis of heparin in ECM scaffolds for tissue engineering applications.
\end{abstract}

Keywords: sulfated glycosaminoglycans; heparin, alcian blue method; method validation; effect of protein; liver-derived extracellular matrix; tissue engineering

\section{Introduction}

Tissue engineering involves the use of a combination of cells, biocompatible scaffold materials, and suitable biochemical factors (e.g., growth factors) to create tissue-like structures and support for regeneration. Scaffolds are primarily composed of proteins and polysaccharides such as proteoglycans (PGs) and glycosaminoglycans (GAGs) that display structural and chemical properties of the native extracellular matrix (ECM) and influence biological activity to promote and regulate the regeneration 
of tissues and organs [1-4]. A study conducted in 1989 demonstrated the potential of PG-coated dishes as a scaffold to enable the self-assembly of primary hepatocytes into multicellular spheroids, which exhibited enhanced liver-specific function. In recent years, there has been heightened interest in using decellularized tissue matrices obtained from processing discarded donor tissue. For example, H. Ijima et al. reported that the solubilized ECM derived from decellularized liver (L-ECM) has the potential to act as an effective scaffold material in the field of regenerative medicine $[1,5,6]$.

PGs and proteins are the two main classes of macromolecules present in the ECM; PGs are major constituents of connective tissues composing blood vessels, cartilage, skin, and neural tissues. Due to their ability to interact with other molecules like cytokines and growth factor receptors, they play a crucial role in cell signaling [7,8]. PGs are bio-macromolecules composed of sulfated GAG (sGAG) chains covalently linked to a protein core. It should be emphasized that sGAG chains form porous hydrated gels and fill most of the extracellular space. The biological functions of PGs depend on the interaction of the sGAG chains with different protein ligands [9].

One of the most common sGAGs is heparin, which consists of repeating units of 1,4-linked pyranosyluronic acid and 2-amino-2-deoxyglucopyranose (glucosamine) residues. Heparin has the highest negative charge density of any known biological macromolecule, where at least $70-80 \%$ of heparin is composed of a trisulfated disaccharide, and the molecular weight distribution of heparin corresponds to its polydispersity. This structural variability makes heparin an extremely challenging molecule to characterize, more sulfated, and is thus more charged than other sGAGs. Furthermore, it is one of the well-known molecules used for tissue regeneration applications [10-12]. sGAGs play an important role in chemical signaling between cells by binding to and regulating the activity of various secreted signaling molecules and proteins $[9,12,13]$.

High performance liquid chromatography [14], nuclear magnetic resonance [15], mass spectrometry (MS) [16], liquid chromatography-MS [17], high-performance anion-exchange chromatography [18], carbazole assay [19], toluidine blue [20], methylene blue [21], and AB assays [22] have been developed to quantify and analyze sGAGs such as heparin in various samples. However, these techniques are time-consuming, sensitive to contamination, costly, and involve complicated procedures. Therefore, there is a need to develop a fast, reliable, and simple method for quantifying heparin. Heparin is widely used as a polyelectrolyte in a multilayer built-up ECM and also for the ECM component of hydrogel materials in tissue engineering applications. Physicochemical studies identify that the thermodynamics and kinetics of protein-heparin binding show a considerable increase in sensitivity over other sGAGs $[3,4,11]$.

More general methods have been established; these quantify heparin by measuring the negatively charged side chains. AB is a well-established assay, which is advantageous over other methods by being reproducible and simple to perform in general lab settings. In numerous studies, AB is commonly used in combination with sGAGs for various methods of quantification and qualification [23]. AB is a polyvalent basic dye with a hydrophobic copper core that interacts electrostatically with tissue-derived polyanionic molecules, such as heparin. The binding of $A B$ to heparin chains is proportional to the number of negative charges present on the heparin chain [24]. In addition, sGAGs are covalently bonded to core proteins residing in the ECM as well as proteins containing a number of negatively charged carboxyl groups and a hydrophobic domain. These carboxyl groups in a protein can be eliminated using the $\mathrm{AB}$ method at a low $\mathrm{pH}$, which might hinder the electrostatic interaction between sGAG and AB $[23,24]$. Clearly, the most prominent interaction type between heparin and a protein is the ionic interaction [12]. Moreover, Alberto L. et al. suggested that the proteins can cause interference with the quantification of carbohydrate [25]. It is very interesting and important to elucidate how heparin- $\mathrm{AB}$ complex is affected by the protein composition.

Our study has focused on the development of an accurate, simple, and reliable AB method to quantify heparin in a sample. Furthermore, the quantitative AB method was validated in accordance with U.S. FDA and ICH guidelines in terms of linearity, limit of detection, limit of quantification, precision, and accuracy $[26,27]$. This study has also discovered the effect of protein in the AB method. 
The basis for this investigation is indicating that fibrous protein inhibits the formation of a heparin- $\mathrm{AB}$ complex, whereas globular protein does not. This effect may be due to the molecular structure of the proteins. After being developed, the $\mathrm{AB}$ method has been successfully applied for the determination of the sGAG amount (expressed as heparin equivalent) in ECM scaffolds from the porcine liver. This $\mathrm{AB}$ method will prove to be very meaningful and effective for quantifying the heparin amount in ECM scaffolds for tissue engineering applications.

\section{Results}

\subsection{Optimization of the AB Method Conditions}

\subsubsection{The Volume Ratio of the Sample and AB Dye}

In this study, two different volumes of the heparin standard ( $25 \mu \mathrm{L}$ and/or $40 \mu \mathrm{L}$ ) were used in triplicate $(\mathrm{n}=3)$ to determine the desired sample volume. A calibration curve was generated by plotting a graph of optical density versus heparin concentration. It is evident that the absorbance or optical density (OD) of a light-absorbing material determined according to the Beer-Lambert's law is directly proportional to the solute concentration in the solution [28]. As seen in Figure 1, the optical density of $40 \mu \mathrm{L}$ of the sample and $\mathrm{AB}$ dye solution was higher than that of $25 \mu \mathrm{L}$ of the sample, and the correlation coefficient for $25 \mu \mathrm{L}$ of sample and $40 \mu \mathrm{L}$ of sample was calculated as 0.996 and 0.998 , respectively. Test results show that $25 \mu \mathrm{L}$ of sample and $25 \mu \mathrm{L}$ of $\mathrm{AB}$ dye solution had comparatively lower optical density. Therefore, the volume of $40 \mu \mathrm{L}$ was selected for further experiments.

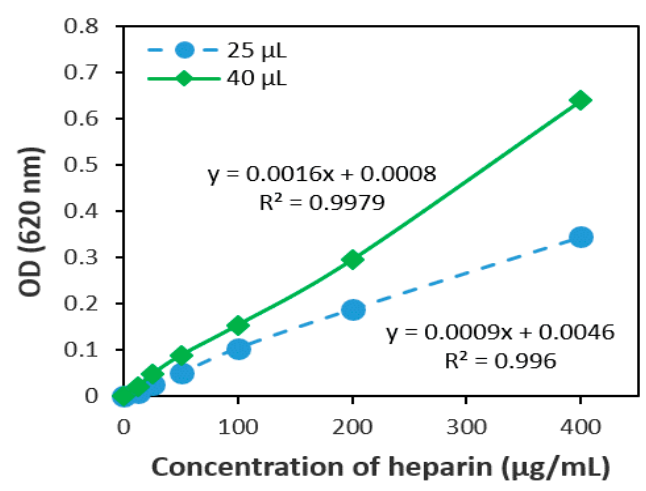

Figure 1. Linearity curves for $25 \mu \mathrm{L}$ and $40 \mu \mathrm{L}$ heparin samples mixed with the same volume of alcian blue $(\mathrm{AB})$. The relationship between optical density and concentration was studied during the colorimetric reaction under experimental conditions. The $\mathrm{R}$ squared value was calculated, and the values depicted represent the mean $(n=3)$.

\subsubsection{Precipitation Time}

Figure 2 shows the correlation between precipitation time and electrostatic attraction between heparin-AB for $24 \mathrm{~h}$ (short), $48 \mathrm{~h}$ (medium), and $72 \mathrm{~h}$ (long). During the experimental period, the optical density of the heparin- $A B$ complex was found to be stable for almost $72 \mathrm{~h}$. It is important to note that our main purpose was to develop a time-efficient method; therefore, we have finalized the precipitation time of $24 \mathrm{~h}$ for the optimized $\mathrm{AB}$ method.

\subsubsection{Solvent Component}

The solvent component was optimized in terms of solvent concentration and compounds' ratio. Thus, various types of solvent components with $\mathrm{NaOH}$ and 2-Aminoethanol were tested to select an appropriate solvent component (Table 1). We measured the optical density of a sample (OD.1), then diluted it 2.5 times using the solvent component and measured the optical density (OD.2) again. An adequate solvent component was selected according to the result of their dilution ratio. A suitable solvent component could reach a dilution ratio of 2.5 . 


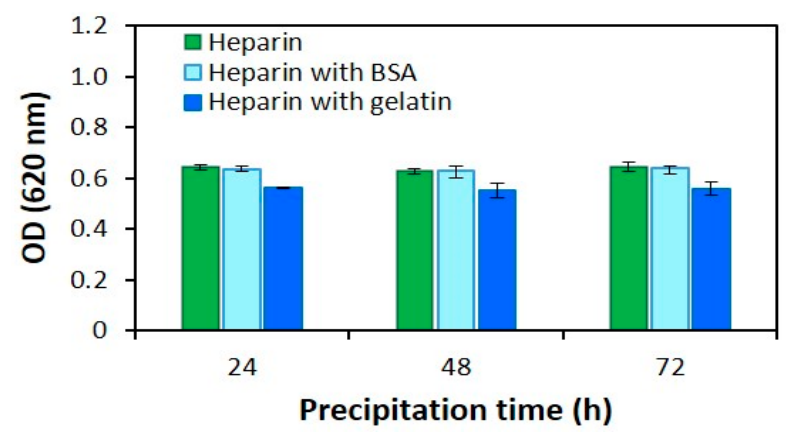

Figure 2. The optical density of heparin sample $(400 \mu \mathrm{g} / \mathrm{mL})$ at different time points $(24 \mathrm{~h}, 48 \mathrm{~h}$, and $72 \mathrm{~h})$ during the precipitation process of heparin-AB. The concentration of proteins was $5 \mathrm{mg} / \mathrm{mL}$. The values given represent the means $\pm \mathrm{SD}$ and mean $(n=3)$.

Table 1. The dilution ratio of different types of solvent components.

\begin{tabular}{ccccc}
\hline Case No. & Chemicals & Ratio & $\begin{array}{c}\text { Final Concentration } \\
\text { of NaOH }\end{array}$ & $\begin{array}{c}\text { The Dilution Ratio } \\
\text { (OD.1/OD.2) }\end{array}$ \\
\hline I & $\begin{array}{c}5 \mathrm{~N} \mathrm{NaOH} \text { and } \\
\text { 2-Aminoethanol }\end{array}$ & $1: 49$ & $0.1 \mathrm{~N}$ & 1.9 \\
\hline II & $\begin{array}{l}5 \mathrm{~N} \mathrm{NaOH} \text { and } \\
\text { 2-Aminoethanol }\end{array}$ & $1: 4.0$ & $1.0 \mathrm{~N}$ & 1.9 \\
\hline III & $\begin{array}{l}\text { 25 N NaOH and } \\
\text { 2-Aminoethanol }\end{array}$ & $1: 24$ & $1.0 \mathrm{~N}$ & 2.2 \\
\hline
\end{tabular}

The data presented in Figure 3 clearly observed that the dilution ratios for the first and second solvents were insufficient while the dilution ratio of the third solvent was higher than that of other solvents. The solvent component consisting of $25 \mathrm{~N} \mathrm{NaOH}$ and 2-Aminoethanol $(1: 24, v / v)$ was determined to be the appropriate solvent component and thus selected for the $\mathrm{AB}$ method.

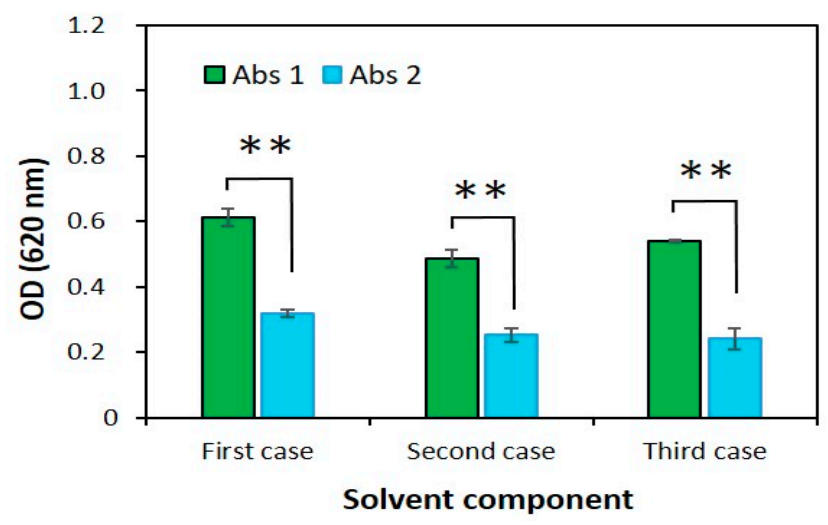

Figure 3. The optical density of the heparin sample $(400 \mu \mathrm{g} / \mathrm{mL})$ in different types of solvent used to dissolve the precipitate. The first case contains $5 \mathrm{~N} \mathrm{NaOH}$ and 2-Aminoethanol, 1:49; the second case contains $5 \mathrm{~N} \mathrm{NaOH}$ and 2-Aminoethanol, 1:4; and the third case contains $25 \mathrm{~N} \mathrm{NaOH}$ and 2-Aminoethanol, 1:24. The data are shown as mean $\pm \mathrm{SD} \mathrm{N}=3$ and ${ }^{* *}$ denotes where $\mathrm{P}<0.01$.

\subsubsection{Solubility Time}

In addition to the solvent component study, we assessed the solubility time by dissolving the precipitation formed upon the heparin- $\mathrm{AB}$ interaction. The solubility was monitored at different time intervals: $0 \mathrm{~min}, 15 \mathrm{~min}$, and $30 \mathrm{~min}$ after adding $1 \mathrm{~mL}$ of solvent component (Figure 4a). The dilution process has been determined in a similar way as described previously for solvent component studies. Briefly, after reading OD.1, $600 \mu \mathrm{L}$ of the solvent component was added to the sample tubes and then 
incubated for different periods of time to completely dissolve the heparin-AB complex. The samples were centrifuged and finally, the OD. 2 was measured at $620 \mathrm{~nm}$ again to indicate the dilution ratio. The difference in optical density at three different time points is minimal whereas the dilution ratios for 0 (zero solubility time), $15 \mathrm{~min}$ and $30 \mathrm{~min}$ were 2.2, 2.4 and 2.5, respectively, as shown in Figure 4b.

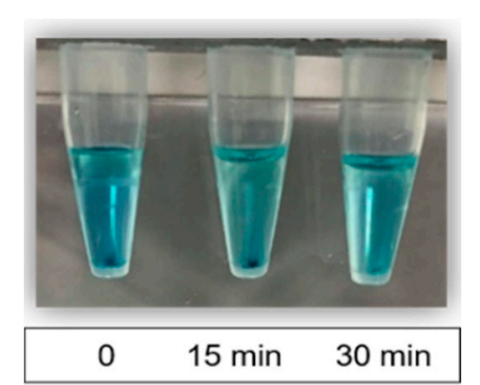

(a)

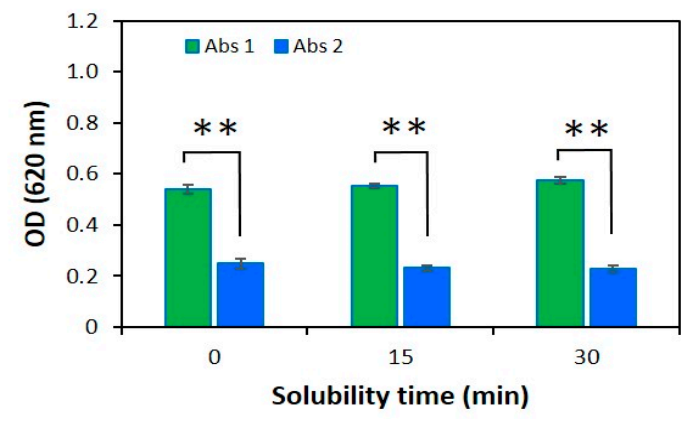

(b)

Figure 4. (a) Appearance of the samples in solubility time study, and (b) The optical density of heparin sample $(400 \mu \mathrm{g} / \mathrm{mL})$ at different time points $(0 \mathrm{~min}, 15 \mathrm{~min}$, and $30 \mathrm{~min}$ ) before and after dilution with the third solvent component, respectively. The data are shown as mean $\pm \mathrm{SDN}=3$ and ${ }^{* *} \mathrm{P}<0.01$.

It is interesting to note that the dilution ratio for zero solubility time was lower than that for other cases while the dilution ratios at $15 \mathrm{~min}$ and $30 \mathrm{~min}$ have given the best results. The solubility time for $30 \mathrm{~min}$ was chosen as this result is close to the theoretical value of dilution ratio. Finally, we reported the general description of the modified AB method in Figure 5.

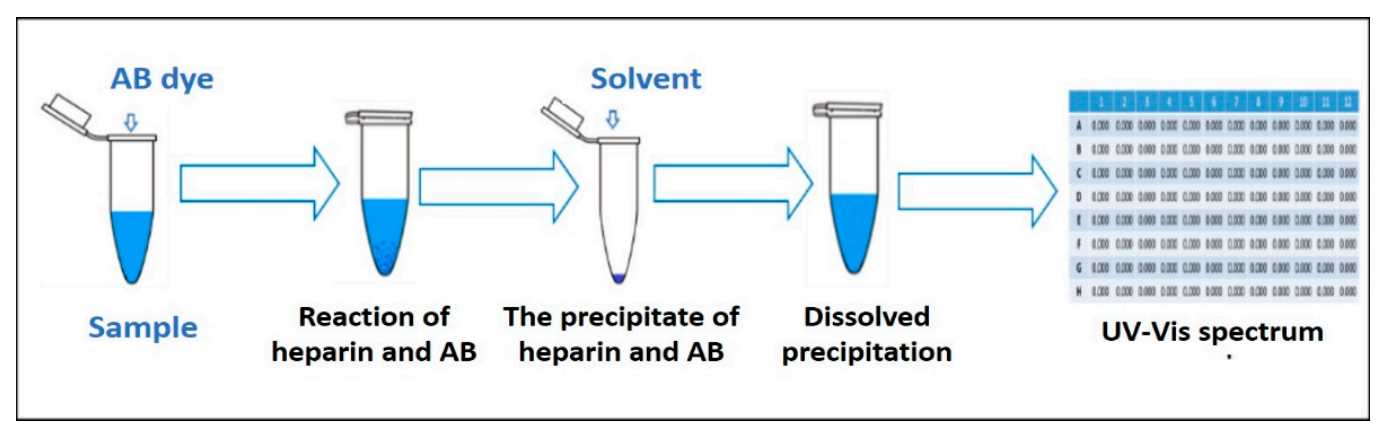

Figure 5. General schema of the AB method.

\subsection{Method Validation}

The modified $\mathrm{AB}$ method was validated in terms of linearity, Limit of detection (LOD) and quantification (LOQ), accuracy, intraday precision (repeatability) and interday precision.

\subsubsection{Linearity}

The linearity of an analytical procedure is the capacity (within a given range) to obtain test results that are directly proportional to the concentration of an analyte in samples [27]. The response of the heparin standard was found to be linear in the investigated concentration range and the regression equation was $y=0.0013 x+0.003$, as shown in Table 2 . The results showed good linearity for heparin, with a correlation coefficient $\left(\mathrm{r}^{2}\right)$ of approximately 0.996 in all cases (Figure 1 and Figure $8 \mathrm{~b}$ ). It can be seen from test results that the calibration curves for heparin were linear within a range of $12.5-400 \mu \mathrm{g} / \mathrm{mL}$. 
Table 2. The concentration and optical density for linearity study.

\begin{tabular}{ccccccc}
\hline $\begin{array}{c}\text { Concentration of Heparin } \\
(\mu \mathrm{g} / \mathbf{m L})\end{array}$ & $\mathbf{4 0 0}$ & $\mathbf{2 0 0}$ & $\mathbf{1 0 0}$ & $\mathbf{5 0}$ & $\mathbf{2 5}$ & $\mathbf{1 2 . 5}$ \\
\hline $\begin{array}{c}\text { Mean OD } \mathrm{OD}^{1}(\mathrm{n}=3) \\
\text { Standard deviation, SD }\end{array}$ & 0.534 & 0.268 & 0.136 & 0.071 & 0.036 & 0.021 \\
\hline
\end{tabular}

${ }^{1} \mathrm{OD}$ is the optical density of heparin at different concentrations

\subsubsection{Limit of Detection (LOD) and Quantification (LOQ)}

In the present study, LOD was found to be $2.95 \mu \mathrm{g} / \mathrm{mL}$, while the LOQ value for heparin was found to be $9.82 \mu \mathrm{g} / \mathrm{mL}$. Here, the LOD value indicates the high sensitivity of the proposed method. Table 3 summarizes the main results from method validation.

Table 3. Quantitative parameters of the heparin calibration curve.

\begin{tabular}{cc}
\hline Parameter & Value \\
\hline$\lambda_{\max }(\mathrm{nm})$ & 620.0 \\
Linearity range $(\mu \mathrm{g} / \mathrm{mL})$ & $12.5-400$ \\
Slope $(\mathrm{b})$ & 0.0013 \\
Intercept $(\mathrm{a})$ & 0.003 \\
Correlation coefficient, $\mathrm{R}^{2}(\mathrm{n}=3)$ & $>0.996$ \\
SE of intercept & 0.0005 \\
SD of intercept & 0.0013 \\
Limit of detection $(\mu \mathrm{g} / \mathrm{mL})$ & 2.95 \\
Limit of quantification $(\mu \mathrm{g} / \mathrm{mL})$ & 9.82 \\
Recovery $(\%)$ & 99.07 \\
\hline
\end{tabular}

\subsubsection{Accuracy}

Accuracy was ascertained by standard samples at different concentrations $(25 \mu \mathrm{g} / \mathrm{mL}, 50 \mu \mathrm{g} / \mathrm{mL}$ and $100 \mu \mathrm{g} / \mathrm{mL}$ ) of heparin. Recovery is often used as a measure of accuracy. This number was determined by calculating the percent mean recovery of the experimentally determined concentration compared to the nominal one [26,27]. The results were expressed as percentage recovery, which was in the range between $97.5 \pm 3.5 \%$, and indicated a high degree of accuracy and absence of interference. The results of the recovery study are shown in Table 4.

Table 4. Accuracy data from three different concentrations of heparin $(n=9)$.

\begin{tabular}{ccccc}
\hline \multirow{2}{*}{$\begin{array}{c}\text { Nominal Concentration of Heparin } \\
(\boldsymbol{\mu g} / \mathbf{m L})\end{array}$} & Case $\mathbf{1}$ & Case 2 & Case 3 & Average \\
\cline { 2 - 5 } & 100.83 & 100.97 & 101.44 & 101.08 \\
$\mathbf{2 5}$ & 98.77 & 94.97 & 100.72 & 98.63 \\
$\mathbf{5 0}$ & 97.67 & 99.95 & 98.36 & 99.09 \\
\hline $\mathbf{1 0 0}$ &
\end{tabular}

\subsubsection{Precision}

The precision of the method was evaluated by determining the relative error (RE, \%), and coefficient of variation (CV) in the intraday and interday variation. The CV (\%) was calculated by assessing the standard deviation and mean value [26]. The intraday precision was determined by duplicate assays at different spiking levels $(25 \mu \mathrm{g} / \mathrm{mL}, 50 \mu \mathrm{g} / \mathrm{mL}$ and $100 \mu \mathrm{g} / \mathrm{mL})$ of heparin standards at the same time. Herein, the CV values determined for an intraday variation were $2.14-4.80 \%$. In addition, the developed method was found to be precise as the CV values determined for interday variation under the same conditions for 3 days were between $3.16 \%$ and $7.02 \%$. Table 5 represents the intraday and interday precisions from this study, where CV did not exceed $10 \%$ in either case. We also 
calculated the mean value of precision, SD and RE in all cases. The RE of $25 \mu \mathrm{g} / \mathrm{mL}, 50 \mu \mathrm{g} / \mathrm{mL}$ and $100 \mu \mathrm{g} / \mathrm{mL}$ sample ranged from 0.34 to 1.19 in the experiment. These statistics were necessary to inspect the variation in datasets.Сельскохозяйственное машиностроение в России: риски и перспективы развития в рамках ВТО

Table 5. Precision and accuracy performance data of reference heparin at different concentration levels.

\begin{tabular}{|c|c|c|c|c|c|}
\hline \multicolumn{6}{|c|}{ Intraday Precision } \\
\hline \multirow{2}{*}{$\begin{array}{l}\text { Nominal concentration } \\
\qquad(\mu \mathrm{g} / \mathrm{mL})\end{array}$} & \multicolumn{3}{|c|}{$\begin{array}{l}\text { Spiked concentration } \pm \mathrm{SD}^{1} \\
\text { mean value, }(\mu \mathrm{g} / \mathrm{mL})\end{array}$} & \multirow{2}{*}{$\mathrm{CV}^{2}(\%)$} & \multirow{2}{*}{$\mathrm{RE}^{3}(\%)$} \\
\hline & No. 1 & No. 2 & No. 3 & & \\
\hline 25 & $24.13 \pm 0.89$ & $24.87 \pm 1.18$ & $25.62 \pm 1.54$ & 4.80 & 0.515 \\
\hline 50 & $51.82 \pm 2.47$ & $50.77 \pm 2.31$ & $47.92 \pm 2.31$ & 4.71 & -0.341 \\
\hline \multirow[t]{2}{*}{100} & $97.46 \pm 2.04$ & $\begin{array}{c}101.28 \pm \\
1.94\end{array}$ & $\begin{array}{c}102.79 \pm \\
2.47\end{array}$ & 2.14 & -0.51 \\
\hline & \multicolumn{3}{|c|}{ Interday precision } & & \\
\hline \multirow{2}{*}{$\begin{array}{l}\text { Nominal concentration } \\
\qquad(\mu \mathrm{g} / \mathrm{mL})\end{array}$} & \multicolumn{3}{|c|}{$\begin{array}{l}\text { Spiked concentration } \pm \mathrm{SD}^{1} \\
\text { mean value }(\mu \mathrm{g} / \mathrm{mL})\end{array}$} & \multirow{2}{*}{$C V^{2}(\%)$} & \multirow{2}{*}{$\mathrm{RE}^{3}(\%)$} \\
\hline & Day 1 & Day 2 & Day 3 & & \\
\hline 25 & $24.87 \pm 1.18$ & $25.18 \pm 2.47$ & $24.59 \pm 1.60$ & 7.02 & 0.48 \\
\hline 50 & $50.77 \pm 2.31$ & $47.49 \pm 2.70$ & $49.97 \pm 4.37$ & 6.33 & 1.19 \\
\hline 100 & $101.28 \pm 1.94$ & $98.77 \pm 2.31$ & $97.67 \pm 5.12$ & 3.16 & 0.77 \\
\hline
\end{tabular}

${ }^{1}$ Standard deviation, ${ }^{2}$ coefficient of variation, and ${ }^{3}$ relative error.

\subsection{The Effect of Protein Structure on the Modified AB Method}

The results of heparin alone, heparin with gelatin and heparin with bovine serum albumin (BSA) samples at different concentrations are shown in Figure 6. As mentioned above, we used also the fibrous protein as gelatin while the globular protein as BSA in this study. In all cases, the optical density of the sample that has different heparin concentration was determined simultaneously. The optical density of heparin with BSA samples had identical values for different concentrations of heparin. This indicates that globular protein does not affect the heparin-AB interaction, while marginal decreases were detected in heparin with gelatin samples when compared to other samples. This result suggests that the quantification reaction between heparin and $\mathrm{AB}$ was subtly influenced by the fibrous protein as gelatin.

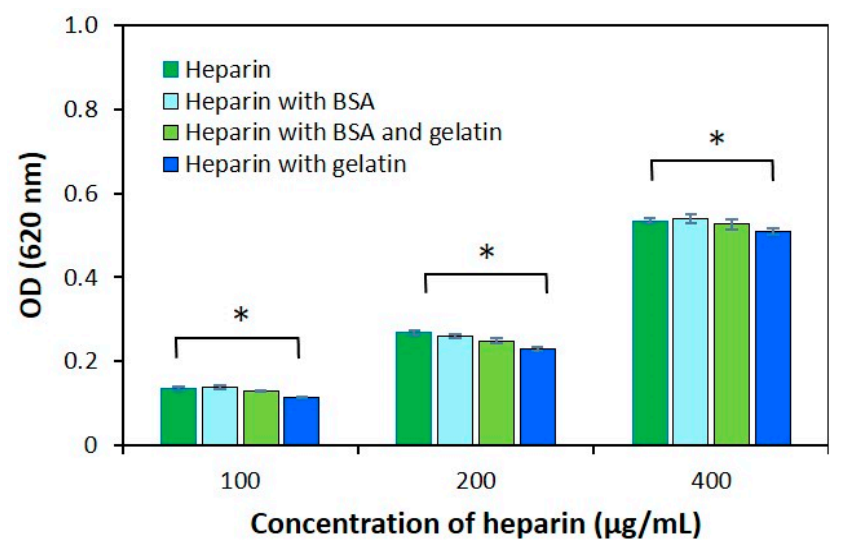

Figure 6. Comparison of the optical density of samples at different concentrations $(100 \mu \mathrm{g} / \mathrm{mL}$, $200 \mu \mathrm{g} / \mathrm{mL}$ and $400 \mu \mathrm{g} / \mathrm{mL}$ ) of heparin alone, heparin with bovine serum albumin, and heparin with gelatin. The concentration of proteins was $5 \mathrm{mg} / \mathrm{mL}$. The data are shown as mean $\pm \mathrm{SD} \mathrm{N}=3$ and * $\mathrm{P}<0.05$. 


\subsection{Quantification of SGAGs in the L-ECM}

An optimized $A B$ method was used to accurately determine the amount of sGAGs in native tissue L-ECM derived from decellularized porcine liver. The experimental design for the preparation of native L-ECM tissue from the decellularized porcine liver scaffold is shown in Figure 7.

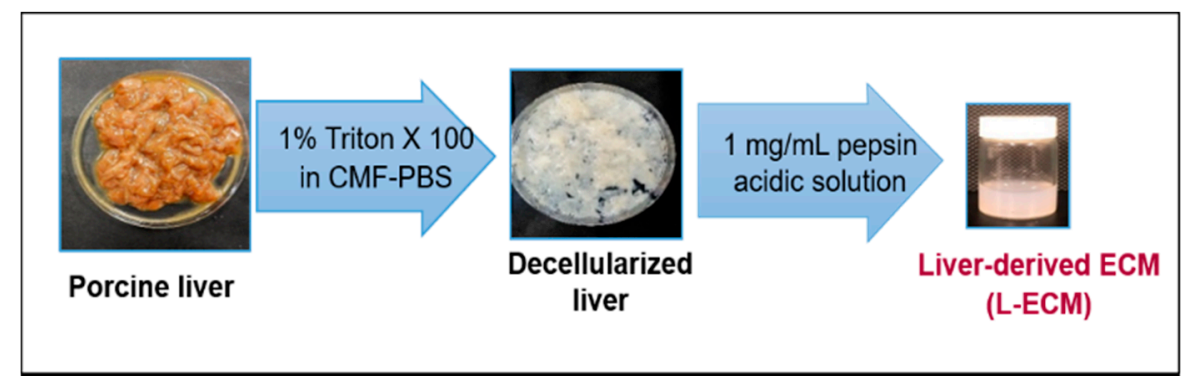

Figure 7. Design of Liver-derived ECM hydrogel preparation.

According to the assay protocol, the collagen quantitation kit was used to determine the concentration of fibrous proteins. Then, the optical density of fibrous proteins in the L-ECM was calculated from the calibration curve of heparin with gelatin samples (Figure 8a). Our result showed that fibrous proteins reduced the optical density to approximately 0.012 . Then, the amount of heparin was calculated accurately from the calibration curve of heparin within a concentration range of $12.5-400 \mu \mathrm{g} / \mathrm{mL}$. The dose-response lines of the heparin with the serial concentration are presented in Figure $8 \mathrm{~b}$. The heparin amount in L-ECM was $40.65 \mu \mathrm{g} / \mathrm{mL}$, expressed as heparin equivalent.

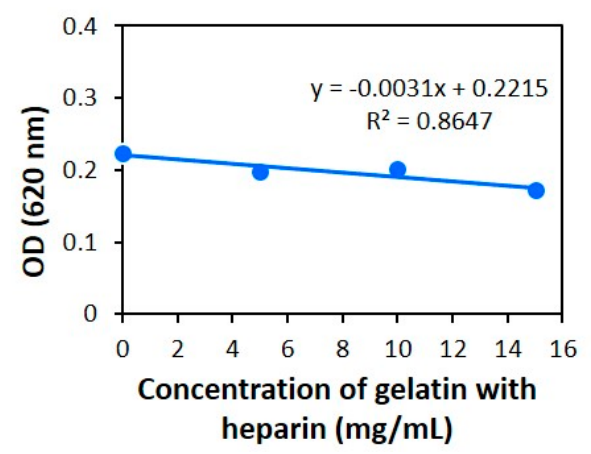

(a)

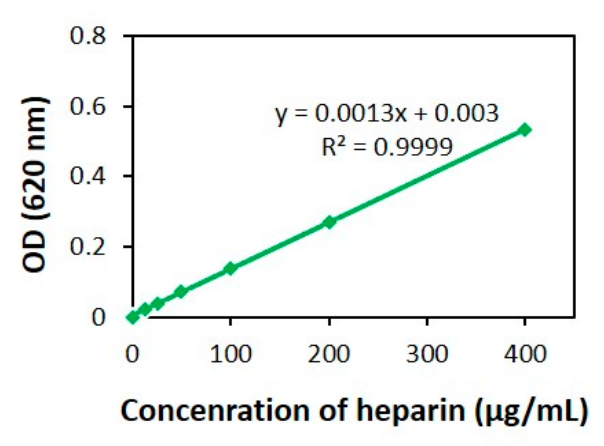

(b)

Figure 8. Calibration curves for (a) $100 \mu \mathrm{g} / \mathrm{mL}$ of heparin with $5 \mathrm{mg} / \mathrm{mL}, 10 \mathrm{mg} / \mathrm{mL}$ and $15 \mathrm{mg} / \mathrm{mL}$ of gelatin sample, and (b) Results were obtained from the concentration range of $12.5-400 \mu \mathrm{g} / \mathrm{mL}$ used for the heparin standard. The $\mathrm{R}$ squared value was calculated, and the values depicted represent the mean $(\mathrm{n}=3)$.

\section{Discussion}

\subsection{Assay Optimization}

$\mathrm{AB}$ has been one of the most widely used cationic dyes for acidic polysaccharides such as sGAGs since 1960. The AB method is based on the formation of a deep blue complex between negatively charged sGAGs and positively charged $A B$ that precipitates out. It was reported that the heparin and $A B$ precipitate is insoluble in water as the ionic bonding between sGAG and $A B$ is a stable interaction [22,23]. As a tetravalent cation-with a hydrophobic core with positive charges attached strongly to heparin-the ionic strength and presence of other interactions affect the precipitate in solution [29]. 
In this study, the volume of sample and $\mathrm{AB}$ dye was tested $25 \mu \mathrm{L}$ and $40 \mu \mathrm{L}$, and the regression coefficients were calculated. Figure 1 shows that the optical density of the $40 \mu \mathrm{L}$ sample and AB was higher than the optical density of $25 \mu \mathrm{L}$ sample and AB.

As noted above, heparin is the most negatively charged biomolecule, and the interaction of heparin with $\mathrm{AB}$ dye produces a blue precipitate that is shown in Figure 4a. The precipitation time conditions (Figure 2) for 72 hours can appear that the time of heparin-AB interaction. Data showed that the extension of time for the precipitation process was unnecessary; a time of $24 \mathrm{~h}$ was adequate for the ionic interaction to take place between heparin and $\mathrm{AB}$.

In addition, solvent component and solubility time were established using three different cases. The difference of the optical density was determined by optical density of the sample and diluted sample. Results are shown in Table 1, Figures 3 and $4 \mathrm{~b}$. Our results of experiments showed that the third solvent component can dissolve the heparin- $\mathrm{AB}$ complex for $30 \mathrm{~min}$.

Finally, we have been established the $\mathrm{AB}$ method where: $40 \mu \mathrm{L}$ of sample and $40 \mu \mathrm{L}$ of $\mathrm{AB}$ reacted for $24 \mathrm{~h}$ in the dark at $4{ }^{\circ} \mathrm{C}$; the solvent component was dissolved using $25 \mathrm{~N} \mathrm{NaOH}$ and 2-Aminoethanol, then incubated for $30 \mathrm{~min}$; lastly, the OD was measured at $620 \mathrm{~nm}$ to determine the amount of heparin in a sample.

In contrast to the $\mathrm{AB}$ method, other methods are unnecessarily time-consuming or expensive [14-19]; toluidine, methylene blue, and other staining method have not been fully explored for routine heparin quantification $[20,21]$. Our newly developed AB method has the advantage of considerably lower consumption of reagents, which are commonly available and easy to prepare chemicals. Therefore, it is cost-effective and requires less analysis time as well. In brief, the modified $\mathrm{AB}$ method is simple and can be readily implemented with the instruments available in a general laboratory setting.

\subsection{Method Validation}

Heparin quantification in biological samples and pharmaceutical products is important for the verification of their quality and is mandatory by many regulatory agencies such as the U.S Food and Drug Administration (FDA) [26]. For this purpose, we validated the modified AB method to quantify heparin. Performance characteristics such as regression coefficient, limit of detection (LOD), limit of quantification (LOQ), intra-and-interday precisions, and accuracy were considered for the validation of the new method.

The detectable range of the $\mathrm{AB}$ method is established between the highest and lowest concentrations with satisfactory accuracy and precision. [22,23]. Under the working conditions, the linear range 12.5-400 $\mu \mathrm{g} / \mathrm{mL}$ of heparin was obtained with a six-point standard curve. The results are shown in Tables 2 and 3. In addition, LOD was the lowest concentration of the analyte that can be detected by a given method; LOQ was the smallest amount of heparin that can be quantitatively measured in a sample with acceptable accuracy and precision. [27]. The value of LOD was $2.95 \mu \mathrm{g} / \mathrm{mL}$, and LOQ was 9.82 $\mu \mathrm{g} / \mathrm{mL}$ (Table 3), thus indicating low LOD and LOQ variation.

Table 4 shows results from accuracy in each analyzed sample. To determine the accuracy of the method, the recovery was found at different concentrations of heparin. The accuracy test for these concentration levels ranged between 94.97 and $100.97 \%$, confirming the reliability of the AB method for determination of the amount of heparin.

The precision of the modified method was calculated according to the International Conference on Harmonization $(\mathrm{ICH})$ guidelines. When the analytical method is repeatedly applied to multiple aliquots of the sample, the precision is the homogeneity of values within a series of individual measurements of an analyte [27]. For the experimental conditions, the CV precision percent of the inter-day (repeatability) ranged $2.14-4.80 \%$. Intra-day (intermedia) variation was calculated by the comparison of sGAGs concentrations obtained from the sample $(n=27)$ performed in three separate assays and the $\mathrm{CV}$ found from 3.16 to $7.02 \%$. For both precision assays in inter-and-intra-days were 
CV lower than the acceptance criteria or $5 \%$ and $10 \%$, respectively. Furthermore, RE was around \pm 1.19 (Figure 5).

Results from the $\mathrm{AB}$ method can be used to evaluate the quality and consistency of analytical procedures. Based on these evaluations, we can claim that the developed $A B$ method has been well-validated.

\subsection{Protein Effect}

Sulfated polysaccharides are capable of very specific interactions with proteins under physiological conditions [29-31]. Some researchers have also considered that the presence of the protein may interfere with carbohydrate estimation [25]. Depending upon the chemical structure, proteins are classified as either fibrous or globular [32]. Therefore, the effect of fibrous and globular proteins on the heparin-AB interaction was determined separately. In addition, some studies mentioned that heparin structure has the capability of interacting with more than one protein and activity should be viewed at the level of their interactions with multiple proteins [11,12]. sGAGs are capable of specific D-periodic binding with collagen fibrils even in the absence of protein cores, an interaction too specific to be due to only the collagen being fibrous [33]. Therefore, it remains an open question as to whether all heparin sequences interact with proteins to some degree and whether synergy effects are more relevant [25].

We tested further to determine that (Figure 6). An evaluation of the spectral properties of the samples showed that it has different spectral properties to gelatin with a heparin sample. Thus, compared with heparin, the optical density was decreased $(p<0.05)$. On the other hand, the heparin-AB interaction was reduced by gelatin. These results confirmed that fibrous protein was affected the optical density of the heparin sample. However, this negative aspect of heparin with gelatin can be explained by fibrous protein behavior. Consequently, fibrous proteins only inhibit the heparin-AB interaction. Globular protein did not interfere in this study. Physically, fibrous proteins are less sensitive whereas globular proteins are more sensitive to changes in $\mathrm{pH}$, temperature, etc. In terms of amino acid sequence, fibrous proteins contain highly repetitive sequences while globular proteins have irregular sequences. Protein behavior can be predicted by the amino acid sequence [34]. It is interesting to investigate the understandings of the chemical properties of the fibrous protein for this method of quantifying heparin.

\subsection{Method Application}

ECM is a non-cellular 3D macromolecular network that is composed of collagen, elastin, fibronectin, laminins, proteoglycans/glycosaminoglycans, and several other glycoproteins. ECM scaffolds have been developed for tissue engineering applications in recent years [2]. Theoretically, hundreds of proteins interact with sGAGs, which are directly involved in various signaling pathways. In addition, sGAG biosynthesis is regulated by a variety of chemokines, cytokines, and growth factors that can enhance or inhibit cell signaling activity $[9,12]$. In both in vitro and in vivo studies, researchers have been able to detect the exact amount of sGAG.

Firstly, we prepared L-ECM as described above. The AB method designed in this paper has been used for the analysis of heparin amount; triplicate measures were taken. The optical density of L-ECM was compared to a standard based on heparin, then total sGAG content was expressed as $\mu \mathrm{g} / \mathrm{mL}$ of heparin. In such sense, the use of the $\mathrm{AB}$ method allows heparin determination in the sample quickly and easily.

In summary, the $\mathrm{AB}$ method, monitored by spectrometry, has been developed for the quantification of heparin in samples. The modified $\mathrm{AB}$ method was validated in terms of parameters, including a determination coefficient, accuracy, coefficient of variation, quantification limit, and detection limit. Interestingly, we found that fibrous proteins inhibit the formation of the heparin- $\mathrm{AB}$ complex, whereas globular proteins do not. The difference might be due to the type and chemical structure of the proteins. Finally, we took the ECM derived from the porcine liver and determined the amount of sGAGs it contained, considering the presence of proteins in the L-ECM, and expressing the results in terms of 
heparin equivalents against a heparin standard curve. As ECM sGAGs have substantially different structures to heparin, the value obtained is likely to be inaccurate in absolute terms. Additionally, our finding suggested that this modified $\mathrm{AB}$ method may be applied to artificial, heparin-containing scaffolds and other wide-ranging applications in the tissue engineering field.

\section{Materials and Methods}

\subsection{Chemicals and Reagents}

The materials and reagents in this study were obtained from the following sources: heparin sodium (1,000,000 units), albumin from bovine serum (BSA, Cohn Fraction V, pH 7.0), and 2-Aminoethanol were purchased from Wako Pure Chemicals (Osaka, Japan). Gelatin from porcine skin (gel strength 300 Type A), Triton X-100, pepsin from porcine gastric mucosa (lyophilized powder, $\geq 2500$ units/mg protein), and Alcian blue 8GX were purchased from Sigma Aldrich Ltd (St. Louis, MO, USA). Collagen type I-C was acquired from Nitta Gelatin Inc. (Osaka, Japan) and collagen quantitation assay kit was acquired from Cosmo Bio (Tokyo, Japan). All other chemicals were of analytical grade. The healthy porcine liver was harvested from adult pigs, Fukuokashokunikuhanbai Co. Ltd. (Fukuoka, Japan).

\subsection{Preparation of Solutions Used in the Method Developing Process}

In this study, $10 \mathrm{mg}$ heparin per $1 \mathrm{~mL}$ of ultrapure water was used as a standard solution from which serial dilutions of heparin standards were prepared in the range of $12.5-400 \mu \mathrm{g} / \mathrm{mL}$.

Thirty milligrams of both gelatin and bovine serum albumin (BSA) were weighed and dissolved in $1 \mathrm{~mL}$ of ultrapure water, and this was further diluted to $15 \mathrm{mg} / \mathrm{mL}, 10 \mathrm{mg} / \mathrm{mL}$ and $5 \mathrm{mg} / \mathrm{mL}$. Gelatin, a fibrous protein, was completely dissolved at $37^{\circ} \mathrm{C}$ in $30 \mathrm{~min}$, while BSA, a globular protein, was dissolved in $10 \mathrm{~min}$.

For $0.1 \%(w / v)$ Alcian blue $8 \mathrm{GX}$ solution, $10 \mathrm{mg}$ of $\mathrm{AB}$ dissolved in $1 \mathrm{~mL}$ of $1 \mathrm{~N}$ hydrochloric acid $(\mathrm{HCl})$.

\subsection{Decellularization and Solubility of the Porcine Liver}

The liver was depleted of blood in a fresh state with calcium and magnesium-free phosphate-buffered saline (CMF-PBS) and cryopreserved at $-80^{\circ} \mathrm{C}$ until use. A porcine liver was sliced to $1 \mathrm{~cm} \times 1 \mathrm{~cm} \times 2 \mathrm{~mm}$ pieces using a mandolin-style slicer and decellularized using $1 \%$ Triton $X-100$ in CMF-PBS at $4{ }^{\circ} \mathrm{C}$ for 3 days to remove the cellular components. The solution was changed each day for 3 days under constant stirring to maintain the efficiency of decellularization. The resulting decellularized liver was immersed in CMF-PBS at $4{ }^{\circ} \mathrm{C}$ for 4 days to remove the detergent. Dialysis was performed to remove salts and impurities using the Spectra/Por 6 dialysis membrane (MCWO: 1000, Spectrum Laboratories, Inc., Milpitas, CA, USA). Finally, lyophilization was done for $24 \mathrm{~h}$ to remove moisture. The dried L-ECM was powdered in a mill mixer and $10 \mathrm{mg}$ of dried L-ECM powder was solubilized in $1 \mathrm{~mL}$ of pepsin solution $(1 \mathrm{~g} / \mathrm{mL}$ in $0.01 \mathrm{~N} \mathrm{HCl})$ and then constantly stirred for 3 days at $4{ }^{\circ} \mathrm{C}$. After that, the ECM solution was centrifuged to remove the supernatant and dialyzed with $1 \mathrm{~L}$ ultrapure water for $24 \mathrm{~h}$. The resulting L-ECM pre-gel $(\mathrm{pH}=3.0-4.0)$ was stored at $4{ }^{\circ} \mathrm{C}$ until further analysis. All animal experiments were performed in accordance with the guidelines of the Ethics Committee on Animal Experiments and accepted by Kyushu University (A27-326-0, 19 February 2016).

\subsection{The Modified AB Method}

Sample and $10 \mathrm{mg} / \mathrm{mL}$ of $\mathrm{AB}$ dye were mixed with at a ratio of 1:1. Sample tubes were then placed in the dark and incubated for $24 \mathrm{~h}$ to facilitate the formation of the precipitate. The remaining dye was removed by centrifugation at $10,000 \mathrm{rpm}$ for $10 \mathrm{~min}$ at $4{ }^{\circ} \mathrm{C}$. The precipitate was resuspended using $1 \mathrm{~N}$ hydrochloric acid $(\mathrm{HCl})$ and centrifuged again at $10,000 \mathrm{rpm}$ for $10 \mathrm{~min}$ at $4{ }^{\circ} \mathrm{C}$ to remove the supernatant. Meanwhile, a solvent component was prepared by dissolving $25 \mathrm{~N}$ sodium hydroxide $(\mathrm{NaOH})$ solution in 2-Aminoethanol $(1: 24 v / v)$ until the mixture became homogeneous. Subsequently, 
$1 \mathrm{~mL}$ of the solvent component was added to the precipitate, mixed using a pipette, vortexed, then placed in the dark for $30 \mathrm{~min}$ and finally centrifuged. All the processes were repeated thrice to completely dissolve the precipitate. After the third centrifugation, $200 \mu \mathrm{L}$ volume of each sample was transferred in duplicates into a 96-well plate, while the solvent solution was used as a blank. Optical density (OD) was measured at $620 \mathrm{~nm}$ within $5 \mathrm{~min}$ after the microplate procedure. OD measurement was performed on a Microplate Photometer from Thermo Scientific (MA, USA).

\subsection{Optimization of the Modified AB Method}

Based on the previous study [20], several tests were conducted to optimize the AB method. For instance, $25 \mu \mathrm{L}$ and $40 \mu \mathrm{L}$ volume of each sample was mixed with AB dye. The crystallization time was tested at $24 \mathrm{~h}, 48 \mathrm{~h}$, and $72 \mathrm{~h}$. Meanwhile, a number of solvent components were prepared with $\mathrm{NaOH}$ and 2-Aminoethanol and lastly, solubility time was varied for $0 \mathrm{~min}, 15 \mathrm{~min}$, and $30 \mathrm{~min}$. While deciding on the solvent component and solubility time, a dilution method for heparin absorption was followed. The dilution ratio of 2.5 was a good indicator in all cases.

The microplate procedure was carried out as described earlier and the optical density (OD.1) of $400 \mu \mathrm{L}$ of sample was measured. Thereafter, $600 \mu \mathrm{L}$ of the solvent component was added to the sample. This solution was then mixed using a pipette, vortexed, then incubated for $30 \mathrm{~min}$ in the dark and finally centrifuged at $10,000 \mathrm{rpm}$ for $10 \mathrm{~min}$ at $4{ }^{\circ} \mathrm{C}$. A volume of $200 \mu \mathrm{L}$ of each diluted sample was placed in duplicates into a 96-well plate and the optical density (OD.2) was measured at $620 \mathrm{~nm}$ again. Alternatively, the value of OD. 2 was equal to the dilution of OD. 1 by 2.5 times.

\subsection{Validation of the Modified AB Method}

The linearity, regression coefficient, y-intercept, slope of the regression line, limit of detection (LOD), limit of quantification (LOQ), intra-and-inter-day precisions and accuracy were analyzed.

Linearity was performed using a calibration curve corresponding to heparin concentration of $12.5-400 \mu \mathrm{g} / \mathrm{mL}$. Triplicates prepared separately at each concentration were analyzed.

LOQ is the minimum quantifiable concentration that was calculated using the standard formula:

$$
3 \cdot \sigma / S
$$

while LOQ was calculated as:

$$
10 \cdot \sigma / S
$$

where $\sigma$ is the standard deviation of the response, and $S$ is the slope of the linear regression $[25,26]$.

Accuracy was calculated as the percentage recovery based on the given formula:

$$
\text { Accuracy }(\%)=\frac{\text { spiked concentration } / \text { nominal concentration }}{100}
$$

The intraday precision, interday precision, and accuracy were estimated by analyzing nine replicates at three different heparin concentrations of $25 \mu \mathrm{g} / \mathrm{mL}, 50 \mu \mathrm{g} / \mathrm{mL}$ and $100 \mu \mathrm{g} / \mathrm{mL}$. The precision was expressed as the coefficient of variation $(\mathrm{CV})$ and relative error (RE) of the replicate measurements

$$
\begin{gathered}
\mathrm{CV}=\frac{\mathrm{SD}}{\text { mean }} \times 100 \%, \\
\mathrm{RE}=\frac{\text { nominal concentration }- \text { spiked concentration }}{\text { spiked concentration }} \times 100 \%
\end{gathered}
$$

The intraday precision was illustrated by nine replicates of heparin samples while the interday precision was determined by these heparin samples on three consecutive days. The acceptance criteria of the data are clearly defined by the FDA guidelines for bioanalytical method validation [24]. 


\subsection{Determination of the Effect of Protein Structure on the Modified AB Method}

In order to determine the effect of protein structure on the heparin quantification, fibrous and globular proteins were selected. Different concentrations of heparin $(100 \mu \mathrm{g} / \mathrm{mL}, 200 \mu \mathrm{g} / \mathrm{mL}$ and $400 \mu \mathrm{g} / \mathrm{mL})$, gelatin $(5 \mathrm{mg} / \mathrm{mL})$, and BSA $(5 \mathrm{mg} / \mathrm{mL})$ were prepared. The effect of protein structure on the $\mathrm{AB}$ method was determined by the optical density of these samples as mentioned above.

\subsection{The Amount of sGAG in Solubilized L-ECM}

To investigate the efficacy of the modified AB method, the amount of sGAGs in solubilized L-ECM was determined with reference to the fibrous protein content. Firstly, the amount of fibrous proteins in the L-ECM scaffold was assessed by a collagen quantification assay kit that uses a fluorogenic reagent, 3,4-Dihydroxyphenylacetic acid (3,4-DHPAA). The assay was performed according to the manufacturer's recommended protocol. We then determined the decreasing optical density of fibrous proteins with gelatin samples using the calibration curve of heparin. Gelatin concentrations with respect to heparin were $5 \mathrm{mg} / \mathrm{mL}, 10 \mathrm{mg} / \mathrm{mL}$ and $15 \mathrm{mg} / \mathrm{mL}$. Finally, the amount of sGAGs in the L-ECM solution was quantified using the calibration curve of heparin standard.

\subsection{Statistical Analysis}

All of the values are presented as mean \pm standard deviation (SD). Statistical comparisons were performed using a two-tailed Student's t-test or one-way analysis of variance (ANOVA). P-values $<0.05$ were considered to indicate statistically significant and P-values $<0.01$ were considered a highly significant difference.

Author Contributions: H.I. and N.S. conceived and designed the experiments; T.I. and R.B. performed the experiments; T.I. and Y.I. analyzed the data; and H.I., T.I., and R.B. wrote the paper.

Funding: This research did not receive any specific grant from funding agencies in the public, commercial, or non-for-profit sectors.

Acknowledgments: The first author wishes to acknowledge Ministry of Education, Culture, Sciences and Sports of Mongolia for the scholarship grant.

Conflicts of Interest: The authors declare no conflict of interest.

\section{References}

1. Berthiaume, F.; Maguire, T.J.; Yarmush, M.L. Tissue Engineering and Regenerative Medicine: History, Progress, and Challenges. Annu. Chem. Biomol. Eng. 2011, 2, 403-430. [CrossRef] [PubMed]

2. Theocharis, A.D.; Skandalis, S.S.; Gialeli, C.; Karamanos, N.K. Extracellular matrix structure. Adv. Drug Deliv. Rev. 2016, 97, 4-27. [CrossRef] [PubMed]

3. Baier Leach, J.; Bivens, K.A.; Patrick, C.W., Jr.; Schmidt, C.E. Photocrosslinked hyaluronic acid hydrogels: Natural, biodegradable tissue engineering scaffolds. Biotechnol. Bioeng. 2003, 82, 578-589.

4. Chevallay, B.; Herbage, D. Collagen-based biomaterials as 3D scaffold for cell cultures: Applications for tissue engineering and gene therapy. Med. Biol. Eng. Comput. 2000, 38, 211-218. [CrossRef] [PubMed]

5. Koide, N.; Shinji, T.; Tanabe, T.; Asano, K.; Kawaguchi, M.; Sakaguchi, K.; Koide, Y.; Mori, M.; Tsuji, T. Continued high albumin production by multicellular spheroids of adult rat hepatocytes formed in the presence of liver-derived proteoglycans. Biochem. Biophys. Commun. 1989, 161, 385-391. [CrossRef]

6. Damania, A.; Kumar, A.; Teotia, A.K.; Kimura, H.; Kamihira, M.; Ijima, H.; Sarin, S.K.; Kumar, A. Decellularized liver matrix-modified cryogel scaffolds as potential hepatocyte carriers in bioartificial liver support systems and implantable liver constructs. ACS Appl. Mater. Interfaces 2018, 10, 114-126. [CrossRef]

7. Schaefer, L.; Roland, M. Proteoglycans: From structural compounds to signaling molecules. Cell Tissue Res. 2010, 339, 237-246. [CrossRef] 
8. Lindahl, U.; Couchman, J.; Kimata, K.; Esko, J.D. Proteoglycans and sulfated glycosaminoglycans. In Essentials of Glycobiology, 3rd ed.; Varki, A., Cummings, R.D., Esko, J.D., Freeze, H.H., Stanley, P., Bertozzi, C.R., Hart, G.W., Etzler, M.E., Eds.; Cold Spring Harbor Laboratory Press: Cold Spring Harbor, NY, USA, 2015; Chapter 17.

9. Sasisekharan, R.; Shriver, Z.; Venkataraman, G.; Narayanasami, U. Roles of heparan-sulphate glycosaminoglycans in cancer. Nat. Rev. Cancer 2002, 2, 521-528. [CrossRef]

10. Dreyfuss, J.L.; Regatieri, C.V.; Jarrouge, T.R.; Cavalheiro, R.P.; Sampaio, L.O.; Nader, H.B. Heparan sulfate proteoglycans: Structure, protein interactions and cell signaling. Acad. Bras. Ciênc. 2009, 81, 409-429. [CrossRef]

11. Meneghetti, M.C.Z.; Hughes, A.J.; Rudd, T.R.; Nader, H.B.; Powell, A.K.; Yates, E.A.; Lima, M.A. Heparan sulfate and heparin interactions with proteins. J. R. Soc. Interface 2015, 12, 20150589. [CrossRef]

12. Ishan, C.; Robert, J.L. Heparin-protein interactions. Angew. Chem. 2002, 41, 391-412.

13. Theocharis, A.D.; Skandalis, S.S.; Tzanakakis, G.N.; Karamanos, N.K. Proteoglycans in health and disease: Novel roles for proteoglycans in malignancy and their pharmacological targeting. FEBS J. 2010, 277, 3904-3923. [CrossRef]

14. Studelska, D.R.; Giljum, K.; McDowell, L.M.; Zhang, L. Quantification of glycosaminoglycans by reversed-phase HPLC separation of fluorescent isoindole derivatives. Glycobiology 2006, 16, 65-72. [CrossRef]

15. Guerrini, M.; Naggi, A.; Guglieri, S.; Santarsiero, R.; Torri, G. Complex glycosaminoglycans: Profiling substitution patterns by two-dimensional nuclear magnetic resonance spectroscopy. Anal. Biochem. 2005, 337, 35-47. [CrossRef]

16. Yu, Y.; Sweeney, M.D.; Saad, O.M.; Crown, S.E.; Handel, T.M.; Leary, J.A. Chemokine-Glycosaminoglycan Binding: Specificity for CCR2 ligand binding to highly sulfated oligosaccharides using FTICR mass spectrometry. J. Boil. Chem. 2005, 280, 32200-32208. [CrossRef]

17. Volpi, N.; Galeotti, F.; Yang, B.; Linhardt, R.J. Analysis of glycosaminoglycan-derived, precolumn, 2-aminoacridone-labeled disaccharides with LC-fluorescence and LC-MS detection. Nat. Protoc. 2014, 9 , 541-558. [CrossRef]

18. Price, K.N.; Tuinman, A.; Baker, D.C.; Chisena, C.; Cysyk, R.L. Isolation and characterization by electrospray-ionization mass spectrometry and high-performance anion-exchange chromatography of oligosaccharides derived from hyaluronic acid by hyaluronate lyase digestion: Observation of some heretofore unobserved oligo. Carbohydr Res. 1997, 303, 303-311. [CrossRef]

19. Platzer, M.; Ozegowski, J.; Neubert, R. Quantification of hyaluronan in pharmaceutical formulations using high performance capillary electrophoresis and the modified uronic acid carbazole reaction. J. Pharm. Biomed. Anal. 1999, 21, 491-496. [CrossRef]

20. Terry, D.; Chopra, R.; Ovenden, J.; Anastassiades, T. Differential Use of Alcian Blue and Toluidine Blue Dyes for the Quantification and Isolation of Anionic Glycoconjugates from Cell Cultures: Application to Proteoglycans and a High-Molecular-Weight Glycoprotein Synthesized by Articular Chondrocytes. Anal. Biochem. 2000, 285, 211-219. [CrossRef]

21. Jiao, Q.; Liu, Q. Characterization of the interaction between methylene blue and glycosaminoglycans. Spectrochim. Acta Part A Mol. Biomol. Spectrosc. 1999, 55, 1667-1673. [CrossRef]

22. Hattori, M.; Arita, J.; Tabuchi, N.; Koike, S.; Nakamura, H. Fractional determination of sodium chondroitin sulfate/hydroxypropylmethyl cellulose mixture using Alucian Blue 8GX. Bunseki Kagaku. 2003, 52, 259-263. [CrossRef]

23. Frazier, S.B.; Roodhouse, K.A.; Hourcade, D.E.; Zhang, L. The Quantification of Glycosaminoglycans: A Comparison of HPLC, Carbazole, and Alcian Blue Methods. NIH Public Access. Open Glycosci. 2008, 1, 31-39. [CrossRef]

24. Scott, J.E.; Quintarelli, G.; Dellovo, M.C. The chemical and histochemical properties of Alcian Blue-I. The mechanism of Alcian Blue staining. Histochemie 1964, 4, 73-85. [CrossRef]

25. Alberto, L.; Anelis, Q.; Meily, S.; Elias, N.R.; Jose, C.; Julio, C.S. Rapid and sensitive anthrone e sulfuric acid assay in microplate format to quantify carbohydrate in biopharmaceutical products: Method development and validation. Biologicals 2008, 36, 134-141. 
26. U.S. Department of Health and Human Services Food and Drug Administration. Center for Drug Evaluation and Research (CDER). Center for Veterinary Medicine (CVM). Guidance for Industry. Bioanalytical Method Validation. May 2018. Available online: http://www.labcompliance.de/documents/FDA/FDA-Others/ Laboratory/f-507-bioanalytical-4252fnl.pdf (accessed on 30 April 2019).

27. Behera, S.; Ghanty, S.; Ahmad, F.; Santra, S.; Banerjee, S. Analytical \& Bioanalytical techniques UV-visible spectrophotometric method development and validation of assay of paracetamol tablet formulation. J. Anal. Bioanal. Tech. 2012, 3, 1656-1661.

28. Ich. ICH Topic Q2 (R1) Validation of Analytical Procedures: Text and Methodology; European Medicines Agency: Amsterdam, The Netherlands, 2005; p. 17.

29. Shrivastava, A.; Gupta, V.B. Methods for the determination of limit of detection and limit of quantitation of the analytical methods. Chron. Sci. 2011, 2, 21. [CrossRef]

30. Karlsson, M.; Björnsson, S. Quantitation of proteoglycans in biological fluids using Alcian blue. Methods Mol. Biol. 2001, 171, 159-173. [PubMed]

31. Mulloy, B. The specificity of interactions between proteins and sulfated polysaccharides. Acad. Bras. Ciênc 2005, 77, 651-664. [CrossRef]

32. Gosline, J.; Lillie, M.; Carrington, E.; Guerette, P.; Ortlepp, C.; Savage, K. Elastic proteins: Biological roles and mechanical properties. Philos. Trans. Soc. B Boil. Sci. 2002, 357, 121-132. [CrossRef] [PubMed]

33. Raspanti, M.; Viola, M.; Forlino, A.; Tenni, R.; Gruppi, C.; Tira, M.E. Glycosaminoglycans show a specific periodic interaction with type I collagen fibrils. J. Struct. Boil. 2008, 164, 134-139. [CrossRef]

34. Peysselon, F.; Ricard-Blum, S. Heparin-protein interactions: From affinity and kinetics to biological roles. Application to an interaction network regulating angiogenesis. Matrix Biol. 2014, 35, 73-81. [CrossRef]

(C) 2019 by the authors. Licensee MDPI, Basel, Switzerland. This article is an open access article distributed under the terms and conditions of the Creative Commons Attribution (CC BY) license (http://creativecommons.org/licenses/by/4.0/). 